\title{
Effects of dietary herbal essential oil mixture and organic acid preparation on laying traits, gastrointestinal tract characteristics, blood parameters and immune response of laying hens in a hot summer season
}

\author{
K. Özek ${ }^{1,3}$, K.T. Wellmann', B. Ertekin ${ }^{2}$ and B. Tarım² \\ ${ }^{I}$ General Directorate of Agricultural Research, Department of Animal and Fisheries Research \\ Mailbox 51, 06171, Yenimahalle, Ankara, Turkey \\ ${ }^{2}$ Poultry Research Institute \\ 06220, Yenimahalle, Ankara, Turkey
}

(Received 2 May 2011; revised version 29 July 2011; accepted 6 December 2011)

\begin{abstract}
In this study, the effects of essential oil mixture, organic acid and essential oil mixture + organic acid supplementation in diets in summer season on egg production traits, egg quality parameters, some digestive system characteristics, some blood parameters and immune response of laying hens were investigated. One hundred ninety two laying hens, 52 wk-old, were divided into 4 treatment groups. There were 48 hens in each treatment group, and each hen was housed individually. The dietary treatments were as follow: 1 . basal diet (negative control), 2 . basal diet $+36 \mathrm{mg} / \mathrm{kg}$ essential oil mixture, 3. basal diet $+2 \mathrm{~g} / \mathrm{kg}$ organic acid, 4 . basal diet $+36 \mathrm{mg} / \mathrm{kg}$ essential oil mixture + $2 \mathrm{~g} / \mathrm{kg}$ organic acid. Laying hens were fed with one of the dietary treatments until 68 wk of age. The treatments had not a significant effect on egg productivity traits but it tends to increase egg weight. However, essential oil mixture supplementation in diet significantly increased albumen height and Haugh unit. No significant differences were observed in serum total cholesterol, glucose and triglyceride levels, and in antibody titer level of Newcastle disease virus (NDV), infectious bronchitis virus (IBV) and infectious bursal disease virus (IBDV) among the treatments, however, supplementing essential oil mixture and organic acid in layer diet tend to improve antibody responses against NDV and IBDV.
\end{abstract}

KEY WORDS: heat stress, essential oils, organic acid, performance, immunity, laying hens

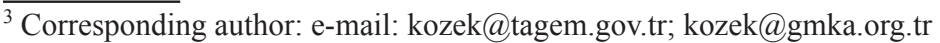




\section{INTRODUCTION}

High environmental temperature has detrimental effect on productive performance of different poultry species (Mashaly et al., 2004; Şahin et al., 2009). In laying hens, heat stress reduces egg production (Mashaly et al., 2004), egg weight (Balnave and Muheereza, 1997), eggshell thickness and strength (Mashaly et al., 2004). Moreover, birds reduce feed intake in high temperatures because of reducing metabolic heat production (Teeter et al., 1985). High temperature not only has an adverse effect on laying performance but also can impede disease resistance. Environmental stress may depress the immune function of birds by impeding production of antibodies and effective cell-mediated immunity (Şahin et al., 2009). For these reasons, heat stress is a big problem in hot region of the world especially in summer season when laying hens are kept in conventional, naturally ventilated houses. Nutritional manipulations with its low cost are preferred to alleviate the negative effects of heat stress on performance of laying hens at least in some regions and farms. Antioxidants, lactic acid, antibiotic, probiotic, prebiotic, vitamins and minerals as a nutritional manipulation tools are commonly added to the diets of birds reared under heat stress (Şahin et al., 2009).

Essential oils extracted from herb and spices are a complex mixture of various compounds, which consist of aromatic and volatile substances (Alçiçek et al., 2003). Two major components of essential oils derived from thyme and oregano are carvacrol and thymol (Bozkurt et al., 2009), and essential oils have some biological properties such as antimicrobial (Dorman and Deans, 2000), antioxidant (Botsoglou et al., 2002), enzymatic (Hernandez et al., 2004), digestion stimulating (Alçiçek et al., 2003). Besides these, essential oils also have anti-heat stress effects and they activate immune system (Çabuk et al., 2006). Organic acids $(\mathrm{OA})$, generated from animals, plants or microorganism in nature, are known to control harmful microorganisms in digestive and respiratory organs of poultry. There are approximately $60 \mathrm{OA}$ classes including lactic, citric, formic and fumaric acids (Park et al., 2009). The most important role of organic acids is to reduce $\mathrm{pH}$ in the stomach and gut (Yeşilbag and Çolpan, 2006). In addition, organic acids improved some immune responses of broilers (Abdel-Fattah et al., 2008). Low gastric $\mathrm{pH}$ accelerates the conversion of pepsinogen to pepsin, which enhances the absorption rate of proteins and minerals (Park et al., 2009). Additionally, OA are able to inhibit microorganism growth in the food, and as a result of this function they preserve the microbial balance in the gastrointestinal tract (Yeşilbag and Çolpan, 2006). Recently, the effects of essential oils in broiler diets have been largely demonstrated (Alçiçek et al., 2003, 2004; Lee et al., 2003). However, it is not well known if the harmful effect of heat stress on productivity and immune function of hens can be overcome by supplementing essential oil and organic 
acids to diet because the effects of essential oils and OA in laying hen diet have not been studied very much especially in summer season.

The aim of this experiment was not only to assess the effects of dietary supplements of either an essential oil mixture (EOM) or OA in diets in hot summer season on laying traits, some digestive system characteristics, some blood parameters, and immune response of laying hens, but also to determine the effects of combined supplementing of EOM and OA in diets.

\section{MATERIAL AND METHODS}

\section{Birds and housing}

One hundred ninety two 52 wk-old ATAK-S laying hens were used in the trial. The trial was conducted in a commercial layer house during the summer season of 2010 between June and September in Ankara, located in central Turkey. The experimental diets and drinking water were offered ad libitum. A photoperiod of $17 \mathrm{~h} /$ day was maintained. The hens were housed in individual layer cages. The layer cages were three floored and $25 \times 47 \mathrm{~cm}$ in size. Hen house temperature was recorded all hours of the day during the experiment. Mean house temperature for each month was calculated from these records. Mean hen house temperatures for June, July, August and September were $26,29,30$ and $28^{\circ} \mathrm{C}$, respectively.

\section{Experimental design and dietary treatments}

One hundred ninety two 52 wk-old ATAK-S laying hens were divided randomly into four treatment groups of 48 birds each, and hens were housed individually. The dietary treatments used in this study were as follow: 1. basal diet (negative control), 2. basal diet $+36 \mathrm{mg} / \mathrm{kg}$ EOM (Heryumix ${ }^{\mathrm{TM}}$, Herba Ltd. Co., İzmir, Turkey), 3 . basal diet $+2 \mathrm{~g} / \mathrm{kg}$ OA (Sal-Tech, Alltech, Dunboyne, Co., Meath, Ireland), 4. basal $\operatorname{diet}+36 \mathrm{mg} / \mathrm{kg} \mathrm{EOM}+2 \mathrm{~g} / \mathrm{kg}$ OA. Heryumix ${ }^{\mathrm{TM}}$, a commercial product including carvacrol, thymol, 1:8-cineole, p-cymene and limonene as active components, composes of 6 different essential oils derived from selected herbs [oregano oil (Origanum sp.), laurel leaf oil (Laurus nobilis L.), sage leaf oil (Salvia triloba L.), myrtle leaf oil (Myrtus communis), fennel seeds oil (Foeniculum vulgare) and citrus peel oil (Citrus sp.)]. Sal-Tech, a commercial product, contains formic acid $24 \%$, propionic acid $15 \%$ and ammonium hydroxide $3 \%$. Supplemented dose rates for EOM and $\mathrm{OA}$ in diet were based on manufacturers' recommendations. The appropriate amount of EOM and OA for $1.000 \mathrm{~kg}$ of feed was premixed with a carrier of 1 and $2 \mathrm{~kg}$, respectively, in order to mix the relevant treatment 
diet. Essential oil premix used $964 \mathrm{~g}$ of zeolite as a carrier for $36 \mathrm{~g}$ of essential oil mixture. Essential oil premix and OA were added as supplements to the basal diet (i.e. $1 \mathrm{~kg}$ of supplement $/ 1.000 \mathrm{~kg}$ of feed was added in place of the sawdust conventionally found in the feed mix). The ingredients and chemical composition of the basal diet are presented in Table 1. Diets were in mash form.

Table 1. The ingredients and chemical composition of basal layer stage 2 diet (52-68 wk)

\begin{tabular}{|c|c|}
\hline \multirow{2}{*}{\multicolumn{2}{|c|}{$\begin{array}{l}\text { Item } \\
\text { Ingredients, } \mathrm{g} / \mathrm{kg}\end{array}$}} \\
\hline & \\
\hline maize & 575.00 \\
\hline soyabean meal & 174.00 \\
\hline sunflower meal & 79.50 \\
\hline full-fat soyabean & 40.00 \\
\hline soyabean oil & 10.00 \\
\hline dicalcium phosphate & 13.00 \\
\hline vitamin premix ${ }^{1}$ & 1.00 \\
\hline trace mineral premix ${ }^{2}$ & 1.00 \\
\hline limestone & 98.00 \\
\hline $\mathrm{NaCl}$ & 3.50 \\
\hline DL-methionine & 2.00 \\
\hline sawdust & 3.00 \\
\hline \multicolumn{2}{|l|}{ Chemical composition, $\%$} \\
\hline dry matter & 90.00 \\
\hline crude protein & 16.00 \\
\hline crude oil & 3.70 \\
\hline crude fibre & 4.20 \\
\hline crude ash & 13.00 \\
\hline starch & 41.80 \\
\hline \multicolumn{2}{|l|}{ Calculated composition } \\
\hline $\mathrm{ME}, \mathrm{MJ} / \mathrm{kg}$ & 12.08 \\
\hline $\mathrm{Ca}, \%$ & 4.20 \\
\hline available $\mathrm{P}, \%$ & 0.35 \\
\hline methionine, $\%$ & 0.44 \\
\hline lysine, $\%$ & 0.80 \\
\hline \multicolumn{2}{|c|}{$\begin{array}{l}{ }^{1} \text { vitamin premix per kg diet: IU: vit. } \mathrm{A} 15000 \text {; vit. } \mathrm{D}_{3} 5000 \text {; mg: vit. } \mathrm{E} 50 \text {; vit. } \mathrm{K}_{3} 10 \text {; vit. } \mathrm{B}_{1} 4 \text {; } \\
\text { vit. } \mathrm{B}_{2} 8 \text {; vit. } \mathrm{B}_{6} 5 \text {; vit. } \mathrm{B}_{12} 0.025 \text {; niacin } 50 \text {; panthothenic acid } 20 \text {; folic acid } 0.25 \text { biotin } 2 \text {; ascorbic } \\
\text { acid } 75 \text {; choline } 175 \\
{ }^{2} \text { mineral premix, per kg diet: } \mathrm{mg} \text { : Mn } 56 \text {; } \mathrm{Zn} 140 \text {; Fe } 56 \text {; } \mathrm{Cu} 10.5 \text {; I } 1.05 \text {; Co } 0.28 \text {; Se } 0.28 \text {; } \\
\text { Mo } 0.7\end{array}$} \\
\hline
\end{tabular}

Tests animals were fed starter (0-4 wk), grower (5-10 wk), developer (11-16 wk), egg starter (17-20 wk), layer stage 1 (21-40 wk) and layer stage 2 diets (41-52 wk) up to starting time of the experiment. The hens were fed with basal layer stage 2 diets during the experiment (52-68 wk). The diets were formulated to meet or exceed NRC (1994) recommendations. The experimental diets were isonitrogenous and isocaloric. Any substance was not added to the diet for improving egg yolk colour. The basal diet was analysed for dry matter, crude ash, crude protein, crude oil, 
crude fibre, sugar, starch, according to analytical recommended by the Association of German Agricultural Analysis and Research Institutes (VDLUFA) methods (Naumann and Bassler, 1993). The metabolizable energy content of the diet was calculated based on chemical composition (Anonymous, 1991).

\section{Variables measured}

Individual body weights of all hens were measured at the beginning ( $52 \mathrm{wk}$ of age) and at the end (68 wk of age) of the experiment to determine changes in body weight. Egg production performance was expressed as a percentage of hen-day egg production. Egg production, broken-cracked eggs and mortality were recorded daily. During the entire experimental period, 30 randomly sampled eggs from each treatment were collected on two consecutive days biweekly. Hence, 960 eggs were weighed to determine average egg weight. Feed intake was recorded on a weekly basis. Egg mass and feed conversion ratios were calculated as below:

Daily egg mass $(\mathrm{g} / \mathrm{hen})=$ hen-day egg production $(\%) \times$ egg weight $(\mathrm{g}) / 100$ Feed conversion ratio $(\mathrm{g}$ feed/g egg $)=$ daily feed intake $(\mathrm{g} / \mathrm{hen}) /$ daily egg mass $(\mathrm{g} / \mathrm{hen})$

To evaluate egg quality, 24 eggs from each treatment once every four week were randomly collected. Hence, 768 eggs from all treatments were collected to determine egg quality. Eggshell thickness, eggshell strength, yolk colour score, Haugh unit (HU) and albumen height as egg quality parameters were examined. Egg parameters were determined $24 \mathrm{~h}$ after collection of the eggs. When determining egg quality characteristics, the sample of eggs were individually weighed at initiation, and then egg shell breaking strength was measured using egg shell tester equipment (Futura resistant tool), and expressed as unit of compression force exposed to unit egg shell surface area $\left(\mathrm{kg} / \mathrm{cm}^{2}\right)$. Then, eggs were cracked and carefully separated from the shells. Egg shell thickness (with membrane) was measured at three different points (i.e. the top, middle and bottom) using a micrometer (model IT-014UT, Mitutoya, Kawasaki, Japan). An average of three different thickness measurements from each egg was used to describe egg shell thickness. The shell was weighted and the relative proportion of shell was determined. Albumen height was measured by Futura equipment electronically. An albumen height gauge that is a part of the Futura egg quality measuring system was used to measure albumen height. The measurements of the albumen height were done on the thick albumen, not touching the yolk and avoiding the chalazae. A Haugh unit was calculated according to the formula given as follow: 
Haugh unit $=100 \log$ [albumen height $(\mathrm{mm})+7.57-1.7$ egg weight $\left.^{0.37}(\mathrm{~g})\right]$

At the end of the experimental period, 6 hens were selected from each treatment group, weighed and slaughtered to determine some digestive system characteristics. After evisceration, pancreas, liver and small intestine without content were weighed individually as well as small intestine length was measured. The weights of these internal organs were expressed as percentages of live body weight. The $\mathrm{pH}$ value of the intestinal digesta (duedonal+jejunal) was determined with a pH meter (Hanna Instruments-8413). Several tubes (eppendorf) were filled with each sample, labeled and centrifuged ( $4000 \mathrm{~g}$ for $10 \mathrm{~min}$ ). The supernatant was withdrawn, and the viscosity of a $0.5 \mathrm{ml}$ aliquot was measured using a Brookfield Digital Viscometer (Model DV-II+PRO, Brookfield Engineering Laboratories, Stoughton, MA, USA) maintained at $40^{\circ} \mathrm{C}$ and expressed in $\mathrm{cP}$.

At the end of the study, $10 \mathrm{ml}$ of blood were drawn from the jugular vein of 6 birds from each treatment for determination of some blood parameters. Feed was not withdrawn from front of the hens before blood was drawn. Serum was separated by centrifugation at $3000 \mathrm{~g}$ for $10 \mathrm{~min}$, and stored at $-20^{\circ} \mathrm{C}$ until the time of analysis. Serum samples were analysed for glucose (glucoseoxidase method; Trinder, 1969), triglycerides (glycerol-3-phosphate-oxidase paraaminophenazone GPO-PAP colourimetric enzymatic method; Trinder, 1969), and total cholesterol (cholesterol-oxidase para-aminophenazone (CHOD-PAP) colourimetric enzymatic method; Roeschlau et al., 1974).

At the beginning ( $52 \mathrm{wk}$ of age) and at the end ( $68 \mathrm{wk}$ of age) of the experiment, $10 \mathrm{ml}$ of blood were drawn from the jugular vein of 6 hens from each treatment for determination of antibody titers level of Newcastle disease virus (NDV), infectious bronchitis virus (IBV) and infectious bursal disease virus (IBDV). A conventional vaccine programme was used for animals. Serum was isolated and stored at $-20^{\circ} \mathrm{C}$. Individual serum samples were analysed for antibody titers levels of NDV, IBV and IBDV by ELISA technique using commercial kits (IDEXX Flockcheck), and the plates were read at $650 \mathrm{~nm}$ on an ELISA reader.

\section{Statistical analysis}

All data were subjected to analysis of variance in the general linear model (one-factor analysis of variance procedure) using the statistical software SPSS 15.0 (SPSS, 2006: Command Syntax Reference, SPSS Inc., Chicago Ill). Posthoc analyses were carried out to determine differences between treatments using Duncan's multiple range test. 


\section{RESULTS}

The productivity and egg quality data of laying hens are summarized in Table 2. There were no significant differences in hen-day egg production, egg weight, egg mass, feed intake, feed conversion ratio, livability, liveweight gain (LWG) and cracked-broken egg ratio. The highest and lowest LWG were obtained in EOM and control group, respectively. As numerical, the highest feed intake, egg mass and egg weight were found in EOM group. The egg weight of EOM group was $2 \mathrm{~g}$ higher compared to the control group. Also, the best feed conversion was obtained in the EOM group.

Table 2. Effects of essential oil mixture (EOM) and organic acid preparation (OA) on performance and egg quality parameters of laying hens

\begin{tabular}{|c|c|c|c|c|c|c|}
\hline \multirow{2}{*}{ Parameters } & \multicolumn{4}{|c|}{ Treatment groups } & \multirow{2}{*}{ SEM } & \multirow{2}{*}{$\mathrm{P}$} \\
\hline & control & EOM & $\mathrm{OA}$ & $\mathrm{EOM}+\mathrm{OA}$ & & \\
\hline \multicolumn{7}{|l|}{ Performance } \\
\hline egg production, hen-day, $\%$ & 78.33 & 77.50 & 75.67 & 76.50 & 0.77 & NS \\
\hline egg weight, $g$ & 66.70 & 68.79 & 66.97 & 66.90 & 0.33 & NS \\
\hline egg mass, g/hen/day & 52.16 & 53.23 & 50.59 & 51.22 & 0.54 & NS \\
\hline feed intake, $g /$ hen/day & 108.18 & 109.90 & 105.48 & 106.47 & 1.09 & NS \\
\hline feed conversion, $g$ feed/g egg & 2.07 & 2.06 & 2.08 & 2.08 & 0.02 & NS \\
\hline liveweight gain, $g$ & 74.00 & 172.00 & 119.00 & 158.00 & 13.90 & NS \\
\hline livability, \% & 99.00 & 98.50 & 99.00 & 100.00 & 0.29 & NS \\
\hline \multicolumn{7}{|l|}{ Egg quality parameters } \\
\hline cracked/broken/ egg ratio, $\%$ & 3.92 & 4.12 & 3.71 & 4.06 & 0.27 & NS \\
\hline egg yolk colour score ${ }^{1}$ & 5.30 & 5.21 & 5.24 & 5.20 & 0.04 & NS \\
\hline Haugh unit score, HU & $76.80^{\mathrm{b}}$ & $80.81^{\mathrm{a}}$ & $78.62^{\mathrm{ab}}$ & $76.52^{\mathrm{b}}$ & 0.54 & $<0.05$ \\
\hline albumen height, $\mathrm{mm}$ & $6.39^{\mathrm{b}}$ & $7.05^{\mathrm{a}}$ & $6.65^{b}$ & $6.40^{\mathrm{b}}$ & 0.08 & $\leq 0.05$ \\
\hline eggshell weight, g & 5.82 & 5.96 & 5.86 & 5.86 & 0.03 & NS \\
\hline eggshell weight ratio, $\%$ & 8.74 & 8.68 & 8.78 & 8.79 & 0.05 & NS \\
\hline eggshell thickness, $\mu \mathrm{m}$ & 324.61 & 320.67 & 326.73 & 331.49 & 1.50 & NS \\
\hline eggshell strength, $\mathrm{kg} / \mathrm{cm}^{2}$ & 3.61 & 3.67 & 3.79 & 3.63 & 0.05 & NS \\
\hline
\end{tabular}

${ }^{1}$ Roche yolk colour score: 1 light yellow; 15 orange

a-b values in the same row not sharing a common superscript differ significantly

SEM - pooled standard error mean; P - probability; NS - not significant

Essential oil mixture and OA supplementations did not affect the outer egg quality parameters (eggshell weight, eggshell thickness, eggshell weight ratio and eggshell strength). However, some inner egg quality parameters (albumen height and Haugh units) were affected by dietary treatments. The albumen height of the EOM group was significantly ( $\mathrm{P}=0.050)$ higher than those of the other groups. The Haugh unit of the EOM group was higher compared to the control and EOM+OA groups $(\mathrm{P}<0.05)$. 
The effects of the dietary additives on relative weight of some internal organs, small intestine long, intestinal $\mathrm{pH}$ and intestinal viscosity are presented in Table 3. Relative internal organ weights except small intestine weight were not influenced statistically by any of the dietary treatments. However, supplementation of EOM and $\mathrm{OA}$ to diet significantly $(\mathrm{P}<0.05)$ affected intestinal $\mathrm{pH}$ and viscosity. The intestinal $\mathrm{pH}$ of $\mathrm{OA}$ and $\mathrm{EOM}+\mathrm{OA}$ groups was lower than those of the other groups. The intestinal viscosities of the $\mathrm{OA}$ and $\mathrm{EOM}+\mathrm{OA}$ groups were lower compared to the control and EOM groups. Feeding OA and OA+EOM supplemented diets decreased $(\mathrm{P}<0.05)$ relative small intestine weights compared to the other groups.

Table 3. Effects of essential oil mixture (EOM) and organic acid preparation (OA) on some gastrointestinal tract, blood and immune response parameters of laying hens

\begin{tabular}{|c|c|c|c|c|c|c|}
\hline \multirow{2}{*}{ Parameters } & \multicolumn{4}{|c|}{ Treatment groups } & \multirow{2}{*}{ SEM } & \multirow{2}{*}{$\mathrm{P}$} \\
\hline & control & EOM & $\mathrm{OA}$ & $\mathrm{EOM}+\mathrm{OA}$ & & \\
\hline \multicolumn{7}{|c|}{$\overline{\text { Gastrointestinal tract parameters }}$} \\
\hline intestinal viscosity, $\mathrm{cP}$ & $1.89^{\mathrm{a}}$ & $1.89^{\mathrm{a}}$ & $1.64^{\mathrm{ab}}$ & $1.49^{\mathrm{b}}$ & 0.06 & $<0.05$ \\
\hline intestinal $\mathrm{pH}$ & $6.22^{\mathrm{b}}$ & $6.30^{\mathrm{a}}$ & $5.96^{\mathrm{c}}$ & $5.92^{\mathrm{c}}$ & 0.06 & $<0.05$ \\
\hline small intestine long, $\mathrm{cm}$ & 128.40 & 128.20 & 130.40 & 123.60 & 1.90 & NS \\
\hline small intestine weight ${ }^{1}, \%$ & $2.39^{\mathrm{a}}$ & $2.46^{\mathrm{a}}$ & $1.83^{\mathrm{b}}$ & $1.88^{\mathrm{b}}$ & 0.086 & $<0.01$ \\
\hline liver weight ${ }^{1}, \%$ & 1.99 & 2.04 & 1.76 & 1.81 & 0.066 & NS \\
\hline pancreas weight $^{1}, \%$ & 0.21 & 0.22 & 0.17 & 0.19 & 0.010 & NS \\
\hline \multicolumn{7}{|l|}{ Blood and immune parameters } \\
\hline glucose, $\mathrm{mg} / \mathrm{dl}$ & 228.20 & 233.00 & 230.00 & 239.30 & 2.790 & NS \\
\hline total cholesterol, $\mathrm{mg} / \mathrm{dl}$ & 157.00 & 192.80 & 189.00 & 203.50 & 12.00 & NS \\
\hline triglyceride, $\mathrm{g} / \mathrm{l}$ & 2.21 & 2.72 & 2.97 & 3.17 & 0.260 & NS \\
\hline \multicolumn{7}{|c|}{ NDV antibody titers (ELISA titers) } \\
\hline at 52 week old & 13756 & 12131 & 12933 & 13398 & 909 & NS \\
\hline at 68 week old & 4291 & 6518 & 5542 & 5927 & 726 & NS \\
\hline \multicolumn{7}{|c|}{ IBV antibody titers (ELISA titers) } \\
\hline at 52 week old & 7715 & 10904 & 6586 & 7068 & 716 & NS \\
\hline at 68 week old & 11610 & 9373 & 7756 & 14434 & 1308 & NS \\
\hline \multicolumn{7}{|c|}{ IBDV antibody titers (ELISA titers) } \\
\hline at 52 week old & 9213 & 9245 & 9132 & 9198 & 216 & NS \\
\hline at 68 week old & 8426 & 8684 & 8968 & 8294 & 535 & NS \\
\hline
\end{tabular}

${ }^{\mathrm{a}-\mathrm{c}}$ values in the same row not sharing a common superscript differ significantly IBV - infectious bronchitis virus, IBDV - infectious bursal disease virus, NDV - Newcastle disease virus, NS - not significant; P - probability; SEM - pooled standard error mean

${ }^{1}$ as percentage of live body weight before slaughter

As shown in Table 3, any serum parameters and immune response were not affected by the treatments. But, it was noted that the total cholesterol and triglyceride values of the control group were numerically lower than those of the other treatments. As numerical, the total cholesterol levels of EOM, OA and $\mathrm{EOM}+\mathrm{OA}$ groups were 17,18 and $23 \%$ higher compared to the control group, 
respectively. Similarly, triglyceride levels of the groups fed diet added feed additive were higher than that of the control group.

\section{DISCUSSION}

Essential oil mixture, $\mathrm{OA}$ and $\mathrm{EOM}+\mathrm{OA}$ supplementation in layer diets resulted in no detrimental effects on general health status. The LWG of the birds fed diets supplemented with EOM, OA and EOM+OA tend to increase compared to the control birds $(\mathrm{P}=0.053)$. The highest $\mathrm{LWG}$ was found in the EOM group. Recent studies indicated that plant extracts supplementation in broiler diets result in growth promotion, nutrient digestibility enhancement, and improvement of feed efficacy in broilers (Alçiçek et al., 2003, 2004). But some author explained that essential oil and OA supplementation to broiler diets did not improve growth (Lee et al., 2003). Previous studies reported that OA and plant extract supplementation to diet have shown different effect on egg production and egg quality of laying hens. This might be stem from amount of OA and plant extract and the source of plant extract and OA. Our findings related to egg production traits did not confirm some earlier work that indicated beneficial effects from essential oils and $\mathrm{OA}$ in the diets of laying hens in summer season. In a recent study carried out in summer season (Çabuk et al., 2006), the hen-day egg production of brown layers between 54 to 74 wk of age that were given diets supplemented with an EOM was significantly higher compared to the control $(\mathrm{P}<0.01)$. Additionally, the beneficial effects of the herbal additives on the egg production rate of laying hens during heat stress were observed in another recent study (Ma et al., 2005). On the other hand, in a study of Park et al. (2009) OA supplementation to a laying hen diet did not affect egg production and egg weight. In our study, egg weights of EOM, OA and $\mathrm{EOM}+\mathrm{OA}$ treatments were numerically higher compared to control treatment. Bozkurt et al. (2009) showed that EOM supplementation in diet did not affect egg production and egg weight of broiler breeders. In another study (Botsoglou et al., 2005), the effects of dietary aromatic plant extracts on the laying performance of hens from 32 to $40 \mathrm{wk}$ of age were investigated, and the results showed no significant differences in egg production and egg weight among the treatment groups.

The results of our study showed no significant differences in eggshell weight, eggshell weight ratio, eggshell thickness, eggshell strength and egg yolk colour among treatments. However, there were significant differences in albumen height and Haugh unit score. Essential oil mixture supplementation in diet significantly increased albumen height and Haugh unit score $(\mathrm{P}<0.05)$. The Haugh unit score is known an indicator of egg freshness and is related to shelf life. The improvement 
in these parameters may indicate that essential oil supplementation can improve egg quality by increasing its shelf life. Consistent with the result of our study, there are several studies that oregano essential oil supplementation in diet did not affect egg weight, eggshell thickness (Botsoglou et al., 2005; Florou-Paneri et al., 2005). On the other hand, Haugh unit results of our study did not agree with results of Botsoglou et al. (2005) and Florou-Paneri et al. (2005) who reported that Haugh unit score was not affected by oregano essential oil supplementation of diet. Yeşilbag and Çolpan (2006) and Park et al. (2009) reported that OA supplementation to diets had no effect on egg weight, eggshell thickness, yolk colour, shell strength and Haugh unit score. The results of our study agree with these results except Haugh unit score. The egg production result of our study were inconsistent with the egg production result of Florou-Paneri et al. (2005) who reported that OA supplementation in diet had a significant effect on egg production.

Significant differences were observed in intestinal viscosity, intestinal $\mathrm{pH}$ and small intestine weight among treatments. As expected, OA supplementation to diet significantly reduced intestinal $\mathrm{pH}$ in the group fed diet added $\mathrm{OA}$ and $\mathrm{EOM}+\mathrm{OA}$ compared to the EOM and the control group.

Organic acids are used in animal nutrition so as to reduce $\mathrm{pH}$ in stomach and intestines. Low $\mathrm{pH}$ level in stomach and intestine suppress growth of acidintolerant bacteria. Thus, organic acids prevent to growth of pathogenic bacteria that negatively affect animal health (Park et al., 2009). This information was confirmed by the results of our study. Organic acid supplementation to diet decreased intestinal viscosity of laying hens in our study $(\mathrm{P}<0.05)$. It is concluded from this result that organic acids can have a feature reducing viscosity in small intestine. We did not find a study that shows organic acid and intestinal viscosity relationship in literature to compare our result. In our study, OA supplementation alone or combined with EOM in diet reduced small intestine weight $(\mathrm{P}<0.05)$. EOM and OA inclusion in diet showed various effects on internal organ weight in previous studies. Our study is consistent with Alçiçek et al. (2004) who reported that organic acids supplementation to diet reduced small intestine weight $(\mathrm{P}<0.05)$.

Neither EOM nor OA supplementation to the diet affected serum glucose, triglyceride and total cholesterol level, but, total cholesterol and triglyceride concentrations tended to increase in treated birds compared to the control. Supplementing EOM, OA and EOM $+\mathrm{OA}$ in diets had no statistically significant advantageous effect on antibody titers against NDV, IBV and IBDV in the summer season, however, as numerical, there were positive effect of additives on antibody titers against NDV and IBDV. The antibody titer levels of NDV for all 
treatments declined from weeks 52 through 68 . Although the changes of antibody titers for NDV (from 52 to 68 weeks of age) over time had similar trends in the all treatments $(\mathrm{P}>0.05)$, the NDV antibody titer levels of EMO, OA and $\mathrm{EOM}+\mathrm{OA}$ treatments were higher compared to control treatment. These results show that EOM and OA supplementation into diet tend to increase immunity. Kong et al. (2006) reported that appropriate doses Chinese herbal ingredients had a positive effect on immune enhancement for chicken. Likewise, it was reported that some organic acids such as citric acid might be a useful for health status of broilers (Chowdhury et al., 2009).

\section{CONCLUSIONS}

Essential oil mixture (EOM) and organic acid (OA) supplementation in laying hen diets in summer season as an anti-heat stress tool and performance enhancer did not show a significant positive effect on performance and immunity but it tend to increase egg weight, antibody responses against Newcastle disease virus and infections bursal disease virus. Moreover, EOM supplementation in diet increased albumen height and Haugh unit score. Collectively, these findings suggest that EOM and OA supplementation in commercial layer diets under heat stress might be beneficial to egg weight and immune function. More detailed studies are still needed to determine the function of EOM and OA supplementation to laying hen diets in summer season.

\section{REFERENCES}

Abdel-Fattah S.A., Ei-Sanhour Y.M., Ei-Mednay H.N.M., Abdul-Azeem F., 2008. Thyroid activity of broiler chicks fed supplemental organic acids. Int. J. Poultry Sci. 7, 215-222

Alçiçek A., Bozkurt M., Çabuk M., 2003. The effects of an essential oil combination derived from selected herbs growing wild in Turkey on broiler performance. S. Afr. J. Anim. Sci. 33, 89-94

Alçiçek A., Bozkurt M., Çabuk M., 2004. The effects of a mixture of herbal essential oil, an organic acid or a probiotic on broiler performance. S. Afr. J. Anim. Sci. 34, 217-222

Anonymous, 1991. Animal feed - determination of metabolisable energy (chemical method). Turkish Standards Institute (TSE), Publication No. 9610, 1-3

Balnave D., Muheereza S.K., 1997. Improving eggshell quality at high temperatures with dietary sodium bicarbonate. Poultry Sci. 76, 558-593

Botsoglou N.A., Florou-Paneri P., Botsoglou E., Datos V., Giannenas I., Koidis A., Mitrakos P., 2005. The effect of feeding rosemary, oregano, saffron and $\alpha$-tocopheryl acetate on hen performance and oxidative stability of eggs. S. Afr. J. Anim. Sci. 35, 143-151

Botsoglou N.A., Florou-Paneri P., Christaki E., Fletouris D.J., Spais A.B., 2002. Effect of dietary oregano essential oil on performance of chickens and on iron-induced lipid oxidation of breast, thigh and abdominal fat tissues. Brit. Poultry Sci. 43, 223-230 
Bozkurt M., Alçiçek A., Çabuk M., Kuçukyilmaz K., Çatli A.U., 2009. Effect of an herbal essential oil mixture on growth, laying traits, and egg hatching characteristics of broiler breeders. Poultry Sci. 88, 2368-2374

Chowdhury R., Islam K.M.S., Khan M.J., Karim M.R., Haque M.N., Khatun M., Pesti G.M., 2009. Effect of citric acid, avilamycin, and their combination on the performance, tibia ash, and immune status of broilers. Poultry Sci. 88, 1616-1622

Çabuk M., Bozkurt M., Alçiçek A., Çatli A.U., Başer K.H.C., 2006. Effect of a dietary essential oil mixture on performance of laying hens in the summer season. S. Afr. J. Anim. Sci. 36, 215-221

Dorman H.J.D., Deans S.G., 2000. Antimicrobial agent from plants: antimicrobial activity of plant volatile oils. J. Appl. Microbiol. 88, 308-316

Florou-Paneri P., Nikolakakis I., Giannenas I., Koidis A., Botsoglou E., Dotas V., Mitsopoulos I., 2005. Hen performance and egg quality as affected by dietary oregano essential oil and -tocopheryl acetate supplementation. Int. J. Poultry Sci. 4, 449-454

Hernandez F., Madrid J., Garcia V., Orengo J., Megias M.D., 2004. Influence of two plant extracts on broiler performance, digestibility, and digestive organ size. Poultry Sci. 83,169-174

Kong X.F., Hu Y.L., Yin Y.L., Wu G.Y., Rui R., Wang D.Y., Yang C.B., 2006. Chinese herbal ingredients are effective immune stimulators for chickens infected with the newcastle disease virus. Poultry Sci. 85, 2169-2175

Lee K.W., Everts H., Kappert H. J., Frehner M., Losa R., Beynen G., 2003. Effects of dietary essential oil components on growth performance, digestive enzymes and lipid metabolism in female broiler chickens. Brit. Poultry Sci. 44, 450-457

Ma D.A., Shan Z., Chen J., Du K., Song J.L., Xu Q., 2005. Effect of Ligustrum lucidum and Schisandra chinensis on the egg production, antioxidant status and immunity of laying hens during heat stress. Arch. Anim. Nutr. 59, 439-447

Mashaly M.M., Hendricks G.L., Kalama M.A., Gehad A.E., Abbas A.O., Patterson P.H., 2004. Effect of heat stress on production parameters and immune responses of commercial laying hens. Poultry Sci. 83, 889-894

Naumann C., Bassler R., 1993. Chemical Analyses of Feedstuff. Method Book III. $3^{\text {rd }}$ Edition. VDLUFA- Press. Darmstadt (Germany)

NRC, 1994. Nutrient Requirements of Poultry. $9^{\text {th }}$ revised Edition. National Academy Press. Washington, DC

Park K.W., Rhee A.R., Um J.S., Paik I.K., 2009. Effect of dietary avaliable phosphorus and organic acids on the performance and quality of laying hens. J. Appl. Poultry Res. 18, 598-604

Roeschlau P., Bernt E., Gruber W., 1974. Enzymatic determination of total cholesterol in serum. Z. Klin. Chem. Klin. Biochem. 12 (5), 226

Şahin K., Şahin N., Kucuk O., Hayirli A., Prasad A. S., 2009. Role of dietary zinc in heat-stressed poultry: A review. Poultry Sci. 88, 2176-2183

Teeter R. G., Smith M. O., Owens F. N., Arp S. C., Sangiagh S., Breazile J. E., 1985. Chronic heat stress and respiratory alkalosis: Occurrence and treatment in broiler chicks. Poultry Sci. 64, 1060-1064

Trinder P., 1969. Determination of glucose in blood using glucose oxidase with an alternative oxygen acceptor. Ann. Clin. Biochem. 6, 24-27

Yeşilbag D., Çolpan I., 2006. Effects of organic acid supplemented diets on growth performance, egg production and quality and on serum parameters in laying hens. Rev. Med. Vet. 157, 280284 